\title{
In Pursuit of Civility: Manners and Civilization in Early Modern England
}

Review Number: 2296

Publish date: Thursday, 29 November, 2018

Author: Keith Thomas

ISBN: 9780300235777

Date of Publication: 2018

Price: $£ 25.00$

Pages: 480pp.

Publisher: Yale University Press

Publisher url: https://yalebooks.co.uk/display.asp?k=9780300235777

Place of Publication: New Haven

Reviewer: Joan Redmond

In one memorable incident related in Keith Thomas's In Pursuit of Civility: Manners and Civilization in Early Modern England, an unfortunate diner fell victim to poor table manners. An Essex farmer 'unluckily helped himself to a gentleman's finger' while carving a piece of fowl, an accident occasioned by the 'eagerness of the company, who all had their hands in the dish at the same time', and the widespread practice of dinner guests bringing their own knives to the meal, and helping themselves to whatever was on offer. It was a custom that persisted until the end of the 18th century, and even beyond (p. 50). This startling incident, sandwiched between a quotation from an 18th-century jest book about fork being a 'spoon with slits in it', and a Huguenot commentary on the English penchant for belching, gives an excellent snapshot of Thomas's lively, engaging and perceptive book on the topic of civility in early modern England.

Thomas sets out as his objective 'an attempt to construct an historical ethnography of early modern England' (pp. 11-12). His focus is most definitely on England (or Britain, depending on chronology), justified through appeal to England's uniqueness in early modern Europe because of its 'highly integrated society', with a common language, strong institutions, and a 'hierarchical but relatively fluid social structure' (p. 12). This characterisation certainly raises some questions, but also excludes to some extent the other constituent parts of 'Britain'. Here the Irish are mostly treated as an 'other', which they often were in English discourses of civility, but a more integrated and comparative account of 'British' civility would perhaps have been an even more insightful book. This is something Thomas acknowledges to some extent, writing that Wales and Scotland receive quite short shrift here. Historians of a more 'British' persuasion may find this aspect of the book somewhat frustrating, although, as will be explored below, Thomas does return to ideas and perceptions of civility in other parts of Britain and Ireland later in the book.

The major themes explored can be broken down into three interlocking strands. There is an examination of manners and expectations of 'civil' behaviour and how these evolved over time, drawing on and synthesising scholarship on numerous important and debated concepts, such as politeness, hierarchy, deference, and courtesy. The second concerns ideas of civility as juxtaposed with barbarism, its supposed antonym. Here civility is explored on what could be described as a macro level, with an investigation of expectations, habits, customs and values at the level of a society, moving out from the polite individual and 
the rules governing their conduct. However, what these expectations, habits and so forth were, was often determined by what they were not: the idea of barbarism was crucial for civility, since civility was often defined as an 'ideal state', with its precise features hard to pin down. Barbarism, however, was clearer: it was violent, lawless, cruel, and lacking in humanitas, a concept that ranged from gentleness to intellectual refinement. The division between civility and barbarism is a crucial foundation for the third major theme, which concerns how civility and barbarism influenced English perceptions not only of themselves, but of other peoples, societies and nations. It also influenced behaviour and policies, especially those surrounding English expansion abroad, whether in Ireland or the Americas. The firm belief that civility and barbarism existed on a spectrum, the capacity - nay, the necessity - to move along that spectrum from barbarism to a civilised condition underlay many English interactions with neighbours both near and far. This marrying of the individual, the social and the global dimensions of civility is stimulating and thought-provoking, and highlights the book's strengths as a gatherer and synthesiser of many different debates and ideas.

The first two chapters (of seven) address early modern ideas of good manners, especially among the higher echelons of society, and how manners and their evolution often reinforced existing social and political hierarchies. The rest of the population is not neglected however, with the relativity of good manners highlighted: courtesy and civility could be exercised by all members of society from high to low, but what constituted acceptable and 'civil' behaviour was governed by social hierarchies and relationships, with expectations regarding due deference and acknowledgment of social status. This exploration of the ways in which the 'meaner sort' could participate in civility serves to balance earlier historiographical emphasis on the middling sort and above, with Thomas pointing out how norms of civility and expectations of behaviour governed interactions between people of lower social status, as well as structing their actions towards their superiors. Religion also features as an important driving force in 'civilising' the lower sorts according to Thomas. Norbert Elias largely dismissed religion as an important factor in his 'civilising process', but here it is properly emphasised: expectations of good behaviour were founded in important Christian ideas of neighbourliness and charity, with the former especially described by Naomi Tadmor as the 'idiom' of daily life in early modern England.(1) The clergy are also identified as key civilising agents, encouraging the best possible manners and conduct from their flock as part of these central Christian beliefs. Nonetheless, Thomas also shows the litany of complaints about the uncivilised and even 'barbarous' English lower sorts, who were frequently depicted as 'rude', 'rustic' or occasionally even as 'savage', a descriptor that called to mind the wild and brutal 'Indians' of America. 'Degrees of civility' is an important term here, and Thomas makes admirably clear the tensions and contradictions of wider English claims to civility, especially when confronted with 'alien' cultures, while also harbouring 'savages' or 'rustics' of its own.

The third and fourth chapters address wider ideas of what it meant to be 'civilised' in the early modern English worldview, including the possibility of evolving from barbarism to civility along the spectrum of civilisation: a journey many early modern English people believed was almost complete in their case. It is here that the oppositional drive of civility and barbarism is central, as such views depended on the existence of barbarism, to self-define oneself as 'civil' or 'civilised'. To a large extent, these self-perceptions were heightened and heavily influenced by contact with other peoples, and especially those in the New World. Older definitions of both the civilised and barbaric condition derived from classical writings, particularly the emphasis on language as a key element of 'civilisation', with the characterisation of languages as 'rude' being an important marker of a people's wider incivility. Likewise, the role of violence in a society, and particularly violence perceived as cruel, was another central marker of barbarism: it was violence that was indifferent to others' pain, and even delighted in it; further, it was violence that was somehow 'inhuman', 'unnatural', and 'unchristian' (pp. 148-50). However, Thomas points out that civility and barbarism were not necessarily tied to religion: non-Christians could be civil, including the ancient societies of China and India. Nonetheless, there was often a religious element that intermixed with more cultural dimensions: one of the sharpest insights here is the elucidation of 'barbarous' versus 'savage', with the latter most often reserved for non-Europeans, and non-Christians. 'Savage' was even lower than 'barbarous', implying even greater distance from the 'civilized' condition, and was typically used for places such as Asia and America. While Europeans could be barbarous, they were not usually savage: thus, a description of a European people as 
savage (not mentioned here, but the Irish occasionally were, for example) carried powerful negative and stigmatising overtones.

However, it was possible for a society or people to move from barbarism to 'civilisation': it was a process that gradually rendered people less barbarous over time. There were several key features, many of which will be familiar to early modern scholars: the emphasis on cultivation and the domestication of animals, the development of towns, and the growth of commerce. However, as Thomas points out, this conception of civility was one that the English held based on their own myth-making, with the strong belief that they had 'emerged' from barbarism - and thus should encourage others to do the same. This in turn influenced their behaviour towards their neighbours, and those further afield. The Welsh for example were believed to have been barbarous in the Middle Ages, a condition ended by the English through their 'improvements'. The Scots, especially the Highlanders, were depicted as barbarous and even savage, and similarly the Irish: though in both contexts, there was a preoccupation with security and conflict that deeply coloured both depictions of these societies, as well as the policies towards them. Throughout, Thomas traces the distinction between more 'cultural' ideas versus 'racial' ones, though theories of the latter were beginning to emerge in this period. Descent had always featured strongly in conceptions of nations and peoples, and with descent came ideas of the 'innateness' of some characteristics, such as the apparently innate barbarism of the Irish and native Americans that could not be fully overcome, and later led to more racialised understandings.

Thomas then moves on to the 'exporting' of civility. We have seen how it operated in English dealings with its Celtic neighbours, with origins far earlier than the early modern period. However, as Europe embarked on a period of renewed expansion, civility emerged as key justification for colonising projects both in Britain itself and further afield. Many of the civility-based justifications for such enterprises have already appeared here, including the claim that primitive societies did not use the land for cultivation, and thus it was 'empty' and primed for taking. Other explanations centred on the necessity of trade, and the right to enter forcefully into a society in order to expand trade, while another argued that since barbarous or savage peoples had no recognisable government or accepted status as a state, they could be legitimately conquered. Many of these points will be familiar to historians of early modern Ireland and the Atlantic world, and here it is woven into a larger fabric of 'progress' and 'civilisation'. Thomas also delicately traces the links between such ideas, and religion: to civilise was not, crucially, to 'gospellise', and there was some disagreement even among church leaders as to the order of 'civilising' and 'converting', with some arguing the need for a basic level of civility before Christianity could be truly embraced. The more sinister ramifications of these rationalisations are also explored here, including the often-brutal conduct of warfare, the suppression of rebellions, and the treatment of the populations in places earmarked as 'barbarous' and ready for conquest. Similarly, civility and barbarism were very visible concepts in the defence of the slave trade, with some arguing that black Africans, as 'barbarous, wild and savage', were not subject to English law and protections, despite the apparently-widespread dismissal in England itself of 'natural slavery' arguments. Civility had a dark underbelly, and Thomas here exposes it to the light, showing its contradictions and the resulting victims, which occurred practically everywhere the English sought to expand to.

The final two chapters deal with contemporary criticisms of 'civility', as well as ideas of relativism. There was a recognition in early modern society, as discussed above, that civility and barbarism were to some extent relative terms, and that 'good' could exist in other societies. One example cited is the Turks: often depicted as the enemy par excellence of the 16th and 17th centuries, there were nonetheless contemporary discussions that they were perhaps not as 'barbarous' and 'cruel' as was often said. Thomas identifies the 18th century as a particular moment in such discourses, with the experience of expansion presenting an opportunity to see and recognise the plurality of peoples and nations, and for some degree of respect for such diversity to emerge. Such tendencies were however mostly quashed in the 19th century according to Thomas, with a renewed emphasis on the polarities of 'civilised' and 'barbarous' societies - though this evolution (or regression?) is not fully explored. This is not to say that the English were necessarily growing more tolerant or cosmopolitan: as Thomas shows, 'foreign' manners and customs were frequently treated with suspicion, especially if they came from so-called 'popish' countries. Within Britain itself, London manners and tastes were often decried as affectations, and innovations to be resisted, again showing the 
tensions and contradictions within the idea of civility and the civilised condition itself. By the end of the 18th century, Thomas argues that the link between 'morality' and 'manners' had mostly disappeared: the latter were outward rules, with little indication of what the inner life cherished and held dear. One could be mannerly, but unethical - a transformation from some 300 years earlier, which saw an unbreakable link between behaviour and Christian ideas of neighbourliness, love, and the welfare of a person's soul.

There can be little doubt that this is an ambitious, sweeping book. One of its chief strengths is in its synthesis of many different areas of scholarship touching 'civility' - from the debates surrounding politeness, to the role of both civility and barbarism in justifying war and conquest in places far removed from London's elite society. It brings many aspects of these arguments together in the attempt to show not only how they were linked, but formed an articulate worldview, applying from the behaviour of an individual, to the conduct of international relations. For that the book will undoubtedly stimulate further debate and research, while also providing a valuable point of entry into the many dimensions to 'civility' and 'civilisation' in the early modern period. A further strength is its efforts to place religion back into the story of civility: the classical origins of many of the concepts under discussion, including but not limited to 'barbarism', can at times obscure the fundamental importance of Christian teachings and practices in such debates. Here Thomas's inclusion of tensions surrounding civilising versus evangelising in colonial settings, can be placed alongside anxieties concerning the apparent rudeness and godlessness of the English peasantry, and the crucial role of clerical figures throughout. There is much more to say about the interaction of religion and civility/barbarism, but Thomas's intervention is a welcome boost for such investigations. On a more prosaic level, this is a book to be enjoyed for its highly engaging style and wide array of sources. The at-times breath-taking jumps between places and periods ensure a lively pace, and the book is packed full of interesting quotations, examples and stories that illuminate as well as entertain, and will doubtless be mined by those interested in just some of the many aspects it touches upon.

This speedy pace does also mean that in places the reader can be left wanting more: its scope means that detailed argument and analysis is sometimes lacking. However, it is not necessarily intended as a specific study of any of the dimensions to early modern civility it addresses: its primary purpose, it seems to me, is to bring together many different areas of scholarship rather than dive into one in particular. That it does extremely well. But the more in-depth student of one or more of its major topics, such as manners and politeness, or the 'exporting' of civility, will likely not find much that is very new here. There is plenty that could still be said on many of the questions and dilemmas this book raises: the reconciliation of 'civility' with slavery, for example, or the relativity or degrees of barbarism. As a historian of early modern Ireland for instance, I found myself wanting more on the comparisons drawn between the native Irish and the English peasantry, and to interrogate more fully the contexts in which such comparisons were made, and to what end. The book is also lacking something of a defined conclusion: it is folded into the final chapter. However, a standalone piece reflecting on the dizzying array of debates, questions and theories investigated here would have been welcome, with a sense of the overall arguments of the book: as it is, we are left somewhat unsatisfied in that regard.

There can be little doubt however that this is a work of impressive scope and ambition, that makes a powerful claim for the twin ideas of civility and barbarism as driving forces of change in the early modern world.

\section{Notes}

1. Naomi Tadmor, The Social Universe of the English Bible: Scripture, Society and Culture in Early Modern England (Cambridge, 2010), esp. pp. 23-49.Back to (1)

\section{Other reviews:}

Guardian

https://www.theguardian.com/books/2018/aug/08/in-pursuit-of-civility-by-keith-thomas-review [2]

New Statesman 
https://www.newstatesman.com/culture/books/2018/06/history-manners-pursuit-civility-keith-thomas-review

[3]

Literary Review

https://literaryreview.co.uk/a-polite-people [4]

Times Higher Education

https://www.timeshighereducation.com/books/review-in-pursuit-of-civility-keith-thomas-yale-universitypress [5]

Spectator

https://www.spectator.co.uk/2018/06/the-short-step-from-good-manners-to-lofty-imperialism/ [6]

Financial Times

https://www.ft.com/content/5eda6818-6b0f-11e8-aee1-39f3459514fd [7]

Source URL:https://reviews.history.ac.uk/review/2296

\section{Links}

[1] https://reviews.history.ac.uk/item/298917 [2] https://www.theguardian.com/books/2018/aug/08/inpursuit-of-civility-by-keith-thomas-review [3]

https://www.newstatesman.com/culture/books/2018/06/history-manners-pursuit-civility-keith-thomas-review [4] https://literaryreview.co.uk/a-polite-people [5] https://www.timeshighereducation.com/books/review-inpursuit-of-civility-keith-thomas-yale-university-press [6] https://www.spectator.co.uk/2018/06/the-shortstep-from-good-manners-to-lofty-imperialism/ [7] https://www.ft.com/content/5eda6818-6b0f-11e8-aee139f3459514fd 